This is a post-referring version of a paper published as:

\title{
The metaethics of nursing codes of ethics and conduct
}

Snelling, P. C. (2016). The metaethics of nursing codes of ethics and conduct. Nursing Philosophy, 17(4), 229-249.

The published version is available at http://onlinelibrary.wiley.com/doi/10.1111/nup.12122/abstract

\begin{abstract}
Nursing codes of ethics and conduct are features of professional practice across the world, and in the UK, the regulator has recently consulted on and published a new code. Initially part of a professionalising agenda, nursing codes have recently come to represent a managerialist and disciplinary agenda and nursing can no longer be regarded as a selfregulating profession. This paper argues that codes of ethics and codes of conduct are significantly different in form and function similar to the difference between ethics and law in everyday life. Some codes successfully integrate these two functions within the same document, while others, principally the UK Code, conflates them resulting in an ambiguous document unable to fulfil its functions effectively. The paper analyses the differences between ethical-codes and conduct-codes by discussing titles, authorship, level, scope for disagreement, consequences of transgression, language and finally and possibly most importantly agent-centeredness. It is argued that conduct codes cannot require nurses to be compassionate because compassion involves an emotional response. The concept of kindness provides a plausible alternative for conduct codes as it is possible to understand it solely in terms of acts. But if kindness is required in conduct-codes, investigation and possible censure follows from its absence. Using examples it is argued that there are at last five possible accounts of the absence of kindness. As well as being potentially problematic for disciplinary panels, difficulty in understanding the features of blameworthy absence of kindness may challenge UK nurses who, following a recently introduced revalidation procedure, are required to reflect on their practice in relation to The Code. It is concluded that closer attention to metaethical concerns by code writers will better support the functions of their issuing organisations.
\end{abstract}

Dr Paul Snelling

Principal Lecturer in adult nursing

Department of Nursing and Midwifery

University of Worcester

Henwick Grove

Worcester

WR2 6AJ

욜 01905542615

p.snelling@worc.ac.uk 


\section{Introduction}

Since their initial appearance in the aftermath of the Second World War, codes of various sorts have been a feature of professional nursing throughout the world, having been seen as an important part of becoming a self-regulating profession (Fry \& Johnstone, 2008).

Codes have a number of stated purposes, including fostering and maintaining the ethical standards of the profession by cultivating character, and providing the regulatory framework by which nurses can be clear about what they are required to do, and against which their performance can be evaluated (Fry \& Johnstone, 2008). In some cases, if conduct falls below a prescribed level, action by the regulator can follow, up to and including removal from the register. Codes have other purposes and audiences, including informing recipients of care what can be expected, and this is made clear at the start of some codes (Nursing and Midwifery Council (NMC) 2015a, Nursing and Midwifery Board of Ireland, 2014). It is common for introductory texts to include three different influences in ethico-legal decision making within professional healthcare: ethical, legal, and professional (Holt, 2010, Gallagher \& Hodge, 2012). So far as introducing professional practice is concerned, this is a good explanation, neatly separating moral questions from legal ones and noting that the nature of practice within a regulated healthcare profession also has a third, professional dimension. A more nuanced account is able to analyse further the features of what are initially presented as professional considerations.

As Johnstsone (2016) noted, codes can be prescriptive and duty centred or aspirational, virtue centred, specifying the ideal nurse. These different types of code, or clauses within a code, are different to an extent similar to legal and ethical considerations about everyday actions. For example, criminal and civil law describes the requirements that define a lawful relationship between me and my neighbour, but adherence to these laws and processes does not define the features of a good neighbour or the sort of neighbour we might aspire to; the sort of neighbour many would like to have living next door, as well as, in reciprocation, the sort of neighbour many would like to be. A lawful neighbour meets legal obligations of maintaining boundaries and avoiding nuisance, but he is not required to watch for rain when the washing is drying or to go to the shops when we are ill. Many of us would like to have a good neighbour but lack of goodness in these terms is not actionable. Courts are not concerned with a neighbour who, for whatever motivation, merely obeys the law and though we might lament the absence of a good neighbour many would settle for a neighbour who complies with the law and who might be said to be a 'good-enough' neighbour or a 'justgood-enough' neighbour. Similarly, some codes or sections of codes set out to describe the features of a good nurse, while others set out minimum standards, below which practice is blameworthy and potentially subject to sanction. Similar to a 'just-good-enough' neighbour these standards describe a 'just-good-enough' nurse, albeit that these minimum standards are higher than can be demanded of the general population (Johnstone 2016).

In this paper I will argue that there is a significant difference between the two different functions of codes, aspirational and regulatory which correspond in important ways to ethical and quasi-legal reasons for action. To be clear, I will refer to codes as ethical-codes and conduct-codes and the clauses within them as ethical-rules and conduct-rules. Generally, published codes fall into one or other of these categories but in some codes the functions are confused and/or conflated. ${ }^{1}$ Though the analysis is weighted towards a UK perspective

\footnotetext{
${ }^{1}$ In a review of the literature on professional ethics based upon a search which specifically excluded papers which concentrated on codes, Kangasniemi et al. (2015) identified professional ethics related to regulation and codes as a key theme.
} 
following revision of the UK regulatory code, differences will be illustrated throughout by examples from codes across the world. Though this inevitably involves some international comparisons, the paper is not intended to be a survey or a systematic analysis. As codes go through regular ${ }^{2}$ revision, systematic comparison would likely become outdated very quickly, and so the analysis proceeds along largely discursive lines with examples drawn from currently available codes rather than a comprehensive text based inductive analysis. I will discuss differences in titles, authorship, level, scope for disagreement, consequences for transgression, language, and character in relation to the difference in function between ethical-rules and conduct-rules. In some cases my analysis demonstrates that conflation of these purposes results in incoherence, and I conclude that clarity between them is necessary for practice, education and regulation. Suggested differences are illustrated in table 1, and further comparisons of codes from different countries are given in table 2 (page 4).

Table 1 - suggested difference between ethics rules and conduct rules.

\begin{tabular}{|l|l|l|}
\hline & Ethics-rules tend to be... & Conduct-rules tend to be... \\
\hline Titles & Code of Ethics & Code of Conduct \\
\hline Authorship & Professional bodies & Regulatory bodies \\
\hline Level & Good nurse & Just-good-enough nurse \\
\hline Disagreement & More subjective & More objective \\
\hline Consequence of transgression & Disapproval, indignation & Official sanction \\
\hline Language & $\begin{array}{l}\text { Descriptive, implying } \\
\text { normative }\end{array}$ & Directive \\
\hline Agent-centred? & Can include character & Excludes character \\
\hline
\end{tabular}

It is not claimed that this table or the arguments it represents are indicative of hard and fast distinctions between what I have characterised as ethics-codes and conduct-codes. Each of the distinctions I propose is contentious and possibly best considered heuristic, and the categories are not always general mutually exclusive. Clearly many wrong actions are wrong under both types of code and rule as well as common morality ad the law. Mindful of the is/ought distinction, I restrict my empirical claims to the approximation that the codes in either category tend to have these features and implied in some of the discussions that follow are normative claims that codes ought to have these features for consistency and clarity.

\section{Titles}

The full title of the UK code is 'The Code: Professional Standards of Practice and Behaviour for Nurses and Midwives' (hereafter The Code). The current version (NMC, 2015a) follows those published in 1983, 1984, 1992, 2002, 2004 and 2008. The founding version was entitled 'Code of Professional Conduct for Nurses Midwives and Health Visitors (based on ethical concepts)', but the word 'ethics' was removed from the title for the 1984, 1992, and 2002 versions, reappearing in the 2004 and 2008 versions before being removed for the current version. In the US (American Nurses Association, 2015) and Canada (Canadian Nurses Association, 2008) there are codes of ethics, but in New Zealand there is a code of conduct (Nursing Council of New Zealand, 2009). Australia has both a code of ethics and a

\footnotetext{
${ }^{2}$ In the UK, the code is in its seventh iteration in 32 years, giving a mean life of just over five years. The NMC Standards and Guidance Review Cycle (NMC 2014a) states that priority will be given to standards over five years old.
} 
Table 2 - International comparison of nursing codes

\begin{tabular}{|c|c|c|c|c|c|}
\hline Organisation & country & Type & Title & Language & Example \\
\hline $\begin{array}{l}\text { International } \\
\text { Council of Nurses }\end{array}$ & International & $\begin{array}{l}\text { Advisory / } \\
\text { professional }\end{array}$ & Code of Ethics for Nurses & Descriptive & $\begin{array}{l}\text { The nurse holds in confidence personal information and uses judgement in } \\
\text { sharing this information (p.2) }\end{array}$ \\
\hline $\begin{array}{l}\text { Nursing and } \\
\text { Midwifery } \\
\text { Council }\end{array}$ & UK & Regulatory & $\begin{array}{l}\text { The Code: Professional Standards } \\
\text { of Practice and behaviour for } \\
\text { Nurses and Midwives }\end{array}$ & Deontic & $\begin{array}{l}\text { you must ... respect a person's right to privacy in all aspects of their care } \\
\text { (Clause } 5.1, \text { p.6) }\end{array}$ \\
\hline $\begin{array}{l}\text { Nursing and } \\
\text { Midwifery Board } \\
\text { of Australia }\end{array}$ & Australia & Regulatory & $\begin{array}{l}\text { Code of Professional Conduct for } \\
\text { Nurses in Australia }\end{array}$ & Descriptive & $\begin{array}{l}\text { Nurses treat personal information obtained in a professional capacity as } \\
\text { private and confidential (Conduct statement } 5, \mathrm{p} .1 \text { ) }\end{array}$ \\
\hline $\begin{array}{l}\text { Nursing and } \\
\text { Midwifery Board } \\
\text { of Australia }\end{array}$ & Australia & Professional & $\begin{array}{l}\text { Code of Ethics for Nurses in } \\
\text { Australia }\end{array}$ & Descriptive & $\begin{array}{l}\text { Nurses value access to quality nursing and health care for all people (Value } \\
\text { statement } 4, \text { p.4) }\end{array}$ \\
\hline $\begin{array}{l}\text { Nursing Council } \\
\text { of New Zealand }\end{array}$ & $\begin{array}{l}\text { New } \\
\text { Zealand }\end{array}$ & Regulatory & Code of conduct for nurses & Descriptive & $\begin{array}{l}\text { Maintain health consumers' confidentiality and privacy by not discussing } \\
\text { health consumers, or practice issues in public places including social media. } \\
\text { Even when no names are used a health consumer could be identified } \\
\text { (Standard 5.8, p.24) }\end{array}$ \\
\hline $\begin{array}{l}\text { Canadian Nurses } \\
\text { Association }\end{array}$ & Canada & $\begin{array}{l}\text { Professional. } \\
\text { Endorsed by } \\
\text { some } \\
\text { provincial } \\
\text { regulators }\end{array}$ & $\begin{array}{l}\text { Code of ethics for registered } \\
\text { nurses }\end{array}$ & Descriptive & $\begin{array}{l}\text { Nurses respect the right of people to have control over the collection use } \\
\text { access and disclosure of their personal information (p.15) }\end{array}$ \\
\hline $\begin{array}{l}\text { The Nursing } \\
\text { Council of Hong } \\
\text { Kong }\end{array}$ & Hong Kong & Regulatory & $\begin{array}{l}\text { Code of Ethics and professional } \\
\text { Conduct for Nurses in Hong } \\
\text { Kong }\end{array}$ & Descriptive & $\begin{array}{l}\text { Nurses ensure that the information given by the individuals in confidence } \\
\text { will only be used for the purposes for which it was given (p.8) }\end{array}$ \\
\hline $\begin{array}{l}\text { Nursing and } \\
\text { Midwifery Board } \\
\text { of Ireland }\end{array}$ & Ireland & Regulatory & $\begin{array}{l}\text { Code of Professional Conduct and } \\
\text { Ethics for Registered Nurses and } \\
\text { Registered Midwives }\end{array}$ & Mixed & $\begin{array}{l}\text { Values descriptive: Nurses and midwives respect each person as a unique } \\
\text { individual. (p.11). } \\
\text { Standards of conduct deontic: You must respect each person as a unique } \\
\text { individual (p.11) } \\
\text { You should respect an individual's advance healthcare directive, if you } \\
\text { know they have one (p.12) }\end{array}$ \\
\hline $\begin{array}{l}\text { American Nurses' } \\
\text { Association }\end{array}$ & USA & $\begin{array}{l}\text { Professional. } \\
\text { Regulatory } \\
\text { in some } \\
\text { states }\end{array}$ & $\begin{array}{l}\text { Code of Ethics for Nurses with } \\
\text { Interpretive statements }\end{array}$ & Mixed & $\begin{array}{l}\text { Provisions descriptive: The nurse's primary commitment is to the patient, } \\
\text { whether an individual, family, group, community or population (p.50. } \\
\text { Interpretive statements mixed, including deontic: Nurses who decide not to } \\
\text { participate on the grounds of conscientious objection must communicate this } \\
\text { decision in a timely and appropriate manner. Such refusal should be made } \\
\text { know as soon as possible (p20) }\end{array}$ \\
\hline
\end{tabular}


code of conduct (Nursing and Midwifery Board of Australia 2008a, 2008b). Hong Kong (Nursing Council of Hong Kong, 2015) and Ireland (Nursing and Midwifery board of Ireland, 2014) have single codes of ethics and conduct. International codes include the International Council of Nursing Code of Ethics (International Council of Nurses, 2006) and the European Federation of Nursing Regulators Codes of Ethics and Conduct for European Nursing (Sasso et al., 2008).

Bradshaw (2015) expressed surprise that the word 'ethics' was excluded from the title and text ${ }^{3}$ of The Code and in a critique of a previous version, Pattison \& Wainwright (2010, p.10) state that:

The interesting point in the NMC Code is that the authors chose to differentiate between conduct and ethics; however, one might have thought that a code of ethics would necessarily include rules of conduct. It is not clear what to make of this separation of conduct from ethics.

The final sentence of this quotation refers to the separation of ethics and conduct in the title rather than substantively throughout the document. They claim that rules of conduct are necessary features of a code of ethics, and so they are, but with some important differences between the types of rules and the codes that contain them, which I will discuss in turn.

\section{Authorship}

When assessing the status of a code it is important to keep in mind the function and purpose of the publishing organisation. The International Council of Nurses ${ }^{4}$ (ICN)(2015) regards its 'three pillars' as relating to professional nursing practice, nurse regulation and socioeconomic welfare of nurses, and these refer to three distinct aims within organisations operating in the environment of nursing practice. Professional bodies like the Royal College of Nursing (RCN) in the UK and the American Nurses Association (ANA) promote nursing practice. Regulators like the NMC aim to protect the public by setting and maintaining educational and practice standards, and nurses' welfare is protected by occupational groups and trade unions. Some organisations fulfil more than one of these aims, and some codes are co-written or endorsed by the different organisation types. In Australia, the Code of Ethics is endorsed by all three, and refers to 'the profession of nursing', but the Code of Professional Conduct is produced by the regulator alone. In Canada where regulation is a matter for provincial government, problems were encountered in the province of British Columbia when the professional and regulatory functions of the Registered Nurses Association of British Columbia were decoupled following legislation (Duncan et al., 2015, Garrett \& MacPhee, 2014), and in the UK, the RCN was criticised by the report into a scandal of poor care for failing to separate its twin functions of professional body and trade union (Francis, 2013, $\mathrm{RCN}, 2013)$. Internationally, codes are issued by organisations operating in all three of these areas and their status and form differs to the extent that they support different organisational aims.

It is important to realise that, in some countries including the UK, regulation is something that is done to health care professions and not something done by a profession. Self-

\footnotetext{
${ }^{3}$ The word ethical can be found once in the new Code, in relation to advertisements and published material (NMC 2015a, clause 21.4, p16).

${ }^{4}$ The ICN is an international body, based in Switzerland with a wide co-ordinating remit decided by its members. It has an interest in regulation, but no direct regulatory powers. In the UK the RCN withdrew from the ICN in 2013 after attempting and failing to negotiate a significant reduction in membership fees (RCN, 2015).
} 
regulation always was contentious as it implied that professionals were not subject to the same scrutiny as other citizens (De Prez, 2002), and nursing regulators never had complete power over numbers of entries to the register, or to shape skill mix (Davies \& Beach, 2000). ${ }^{5}$ If codes initially contributed to a professionalising agenda, they have increasingly been seen as mechanisms of managerialism (Traynor et al., 2014) and control (Meulenbergs et al., 2004). Fry \& Johnstone (2008, p.57) refer to this as a 'tool for peer review', but this overstates the notion of collegiality. Boards and managers do not investigate the actions of their peers but their supplicants. Pyne ${ }^{6}$ (1992) demonstrates that even as the first UK Code was being produced in 1983, self-regulation was primarily concerned with discipline, reflected in the title of his book: 'Professional discipline in nursing, midwifery and health visiting'.

Following a number of healthcare scandals (Hutchinson, 2015) professional self-regulation in the UK was finally laid to rest following enactment of the white paper Trust Assurance and Safety (Secretary of State for Health, 2007), which was specifically aimed at making regulators independent from the 'health professionals themselves' (p. 24). From $1^{\text {st }}$ January 2009 there has had to be parity of membership between professional and lay members on governing councils of healthcare regulators. In addition, registrant members of governing councils were no longer to be elected but appointed by the government. ${ }^{7}$ Currently, ${ }^{8}$ neither the Chair nor the Chief Executive nor any of the senior management team of the NMC is a nurse or a midwife (though one was a radiographer).

In the now fully post professional phase of regulation (Illych, 1977, Meulenbergs et al., 2004), the extent of government control, in contrast to legislative oversight, can be seen in NMC Board papers, where standards development, including the Code and associated documents is prioritized by a number of considerations including meeting 'ministerial or political imperative' (NMC, 2014b, p.2), flatly contradicting the intention set out in Trust assurance and Safety: Stakeholders... 'must be separate from the Government, constitutionally insulated from day-to-day political pressures' (Secretary of State for Health, 2007, p.24). With the aim of protecting the public, conduct-rules can be set out by legislators, but ethical-rules which require detailed knowledge and understanding are developed and promulgated from within a profession. Even if development includes engagement with other professions and service users, ethical-codes, as seen for example in the US and Canada, are developed by nurses themselves usually via professional organisations.

There is often wide consultation as codes are developed and they are seldom written by identified individuals (Pattison, 2001). The ANA Code of Ethics Revision Professional Issues

\footnotetext{
${ }^{5}$ Possibly as a result of protracted debate about minimum staffing levels, the NMC clearly states on its website that it is not responsible for setting minimum staffing levels (NMC, 2015b).

${ }^{6}$ This is of special interest as the author, Reg Pyne was Assistant Registrar at the United Kingdom Central Council for Nursing, Midwifery and Health Visiting (UKCC) which was the predecessor of the NMC

${ }^{7}$ This is contentious. Appointments are ratified by the Privy Council, an ancient body whose function is to advice the Monarch. Its approximately 600 members are mainly senior politicians, though the meeting in July 2015 was attended by just four and the Queen. As far as appointments to healthcare regulators is concerned the Privy Council 'rubber stamps' appointments made by the Centre for Public Appointments which is part of the Cabinet office, a government department.

${ }^{8} 11^{\text {th }}$ January 2016
} 
Panel Advisory Committee has over 300 members $^{9}$ and the UK code underwent wide consultation during development (NMC, 2014c). Organisations were consulted, and there were 1649 individual responses. Even if all of these were individual nurses, this would represent fewer than 1 in 150 registered nurses. Significant changes to the draft which were not identified during consultation were also made (Snelling, 2015), so though there might be considered to be wide contribution to codes, this falls a long way short of shared authorship.

\section{Level.}

As Johnstsone (2016) noted, codes can be prescriptive or aspirational in nature. Prescriptive (conduct) codes are duty centred, whilst aspirational (ethical) codes are often virtue or value centred, specifying the ideal nurse. The purpose of prescriptive codes is to establish minimum levels of conduct such that anything below this runs the risk of attracting investigation and sanction. For example from the UK code:

When joining the register nurses and midwives commit to upholding these standards. This commitment to professional standards is fundamental to being part of a profession. We can take action if registered nurses or midwives fail to uphold the Code. In serious cases, this can include removing them from the register.

(NMC, 2015a, p.2)

All nurses have known colleagues who are inspirational just as we have known some who are less so - we can call to mind images and memories of excellent nurses, good nurses, verypoor-nurses-who-shouldn't-be-nurses, and nurses who are just-good-enough, complying with rather than conforming to the conduct-rules expressed in a code (Spielthenner, 2015). Educators are familiar with this level as it is analogous to the learning outcomes of a module or programme or study. These also represent what must be achieved, such that any student not meeting this minimum level will fail the module, though just attaining the pass mark is not generally indicative of a good student. Similar to a high achieving student, there is considerable scope for a nurse's conduct to exceed the prescribed minimum, in both conduct and character, and this rather than mere observance of the code articulates the properties of a 'good' nurse.

Conduct-codes and rules explain to nurses (and the public) just what these minimum standards are, and they can be used by educators to explain the minimum nature of professional practice to students. They are also used by disciplinary panels in investigating nurses whose conduct falls below the stipulated minimum. For all of these purposes it is important that the level of described practice is clear. In the UK, The Code states that:

While you can interpret the values and principles set out in the code in a range of practice settings, they are not negotiable or discretionary. [...] They are the standards that patients and members of the public tell us they expect from health care professionals. They are standards shown every day by good nurses and midwives across the UK.

(NMC, 2015a p.2)

\footnotetext{
${ }^{9} \mathrm{~A}$ full list is available at http://www.nursingworld.org/MainMenuCategories/EthicsStandards/CodeofEthicsforNurses/Revision-of-Codeof-Ethics-Panel/Ethics-Code-Revision-Advisory-Committee-Members.pdf
} 
It is true that these minimum standards shown by just-good-enough nurses are also shown by good nurses but they are not definitive of them. On the following page the relationship between the standards and good practice is expressed differently so that now a just-goodenough nurse, complying to the standards looks like a good nurse:

The Code contains a series of statements that taken together signify what good nursing and midwifery practice looks like.

(NMC, 2015b p.3)

The Code conflates good nursing with just-good-enough nursing. The paper presented to the Council meeting that approved the latest version of The Code rightly noted that:

[...] the Code is not an 'aspirational' document but a clear statement of the professional standards everyone should be able to expect from a nurse or midwife.

(NMC, 2014a, p. 3)

And yet The Code itself includes the statement that you must:

Act as a role model of professional behaviour for students and newly qualified nurses to aspire to. ${ }^{10}$

(NMC, 2015a, clause 20.8, p.15)

The conflation of minimum standard and aspiration without elaboration demonstrates conceptual confusion and this as much as ambiguous wording throughout makes the current version of The Code poor at guiding practice (Snelling, 2015).

\section{Scope for disagreement.}

A further distinction to be drawn between ethical-rules and conduct-rules is that ultimately, like legal requirements, conduct-rules are objective insofar as the rule really is there and can be enforced. A starving man stealing food from a supermarket commits a crime, and arguments that it was not wrong, or that it was wrong but justified do not alter that fact. He may escape prosecution or a severe sentence because of mitigating circumstances, but he cannot claim that it is lawful. It just is not. ${ }^{11}$ Similarly, we might want to deny that it is unethical or unprofessional to use, for example, earthy (irresponsible) language on social media or to enter into a personal relationship with a former patient, or to use our status as a Registered Nurse to promote a cause unrelated to health, but there are clauses in The Code forbidding all of them. Ethical judgements are subject to genuine and irresolvable disagreement in ways that legal and regulatory matters are not, even taking into account difficulty in interpretation and lack of explanatory guidance. A more modest claim relating to matters of extent rather than kind may be made; that though I accept, that earthy (irresponsible) language is unprofessional in principle, the actual words I have used are not unprofessional. It may be a source of considerable irritation that I cannot be clear by reading the code and associated guidance just what I am allowed to say, but argument about moral status and interpretation will count for very little in a fitness for practice hearing. If the panel concludes that the language or the relationship are unprofessional or irresponsible, or a gift

\footnotetext{
${ }^{10}$ It's a curious clause also because in applying to all nurses and midwives it apparently requires newly qualified nurses to be role models for themselves

${ }^{11}$ I don't count rare instances of jury nullification, where a jury can decline to convict where the evidence requires it (Freedman, 2013)
} 
non-trivial, then that settles the matter. The view of the panel prevails, measured against conduct-rules rather than ethical-rules, and clearly this has implications for the possibility of sanctions.

\section{Consequences for Transgression}

Pattison \& Wainwright's (2010) view that codes of ethics contain rules within them is right insofar as statements of value can be specified to a situation and provide action guidance. Specification is a feature of many systems of ethical analysis including, notably, the ubiquitous four principles of bioethics (Beauchamp \& Childress, 2013, Edwards, 2009), which applies rules derived from principles and theories to specified situations. So an ethical value statement that nurses value people and communicate effectively might be specified to an ethical rule that in order to support communication, nurses ought to use language that their patients can understand. It would be unethical to use technical terms and complex statistics without explanation or continue an explanation without pausing to check understanding. A nurse acting in this way would not be respecting her patient and as a result she would be considered blameworthy, and the patient may feel indignant or at the very least think less of her. She would not be considered a 'good nurse'. In common morality, a similar response would greet a bibliophile friend who insisted on giving a lengthy explanation of his liking for a book in terms that outstripped my understanding or interest.

This matter is addressed directly by The Code which states that you must 'use terms that people in your care, colleagues and the public can understand (NMC, 2015a, para 7.1, p. 7) and you must 'check people's understanding from time to time to keep misunderstanding or mistakes to a minimum' (para 7.4, p. 8). Now if the nurse behaves in the unethical way described, she has also acted against The Code. She has broken the quasi-legal precept set by an organisation that has power over her, and because she has broken the rule, she is liable to be punished ${ }^{12}$ for it. If she is censored or punished it is because she broke the conduct-rule and not because she broke the moral-rule. The distinction is important even if the rule amounts to the same thing.

It is possible, by design or oversight, that a code is a hybrid document consisting of both ethical-rules and conduct-rules. If that is the case, then the language in which the code is written must be able clearly to identify the status of each clause. In the next section, the deontic language of codes will be examined.

\section{Language}

Table 2 details the titles of Codes with examples of clauses. Many clauses are descriptive; they are written so as to say what nurses do. For example, from the Canadian Nurses Association (CNA), a professional organisation, whose code also fulfils regulatory functions in some provinces: 'Nurses respect the right of people to have control over the collection, use, access, and disclosure of their personal information' (CNA, 2008, p.15). Others use modal verbs addressed to individual nurses indicating the nature and extent of their obligations.

\footnotetext{
${ }^{12}$ In fact the NMC indicative sanctions to panels state very clearly that their purpose is for public protection and not punishment: 'It must be accepted that sanctions may have a punitive effect, but this is not their purpose.' (NMC, 2012, p.5). Discussion about the difference between punishment and sanction (if there is one in this context) lies outside the scope of this paper.
} 
Modal verbs, can, may, should and must have a number of meanings (Groefsema, 1995). In codes they are used normatively, that is they are action guiding. In everyday use, the words 'should' and 'must' have similar meanings though with different strengths so that 'must' is generally more imperative than 'should' (Groefsema, 1995). There is a difference between:

(1) You should visit your brother more often, and

(2) You must visit your brother more often.

Meaning can be augmented:

(3) You really should/must visit your brother more often.

And can also appeal to aesthetic or prudential matters:

(4) You (really) should / must go and see more plays.

(5) You (really) should /must dye your hair (if you want to look younger).

Individuals can utter these sentences to themselves (I should/must read more), and more generally the status of the person making the normative claim also has importance, formally through power structures like regulatory bodies and less so through informal bonds. My mother's injunction, however expressed, that I visit my brother more often has a different meaning and strength than my friend's or my own, though this is not true of all mothers and all friends. In this informal sense all that we can say is that there is often a difference between pretheoretical uses of these words.

Some codes use deontic language. In interpreting statements of provision, The ANA Code offers normative explanatory statements: 'Nurses who decide not to participate on the grounds of conscientious objection must communicate this decision in a timely and appropriate manner. Such refusal should be made known as soon as possible' (ANA, 2015, p.20 emphasis added). Here and throughout the document the deontic words 'must' and 'should' are used interchangeably, with justification supplied at the start:

The English language continues to evolve and the once firm and clearly understood distinctions between may and can; will and shall; and ought should and must have faded in daily language and have come to be used interchangeably in both speech and writing, except in rare instances in which the nuance is essential to an argument. To aid the reader in understanding the terms used this version of the ANA's Code of Ethics with Interpretative Statements will, for the first time, include a glossary of terms that are found within the Code.

(ANA, 2015, p. xiii. Emphasis in original)

There is indeed a glossary at the end of the document, but none of the italicised words can be found within it, and so the ANA clearly does not accept that the 'nuances' of the words are essential here. There are, however, some bold normative claims. For example:

Nurses must address the context of health including social determinants of health such as poverty, access to clean water and clean air, sanitation, human rights violations, hunger, nutritionally sound food education safe medication and health care disparities.

(ANA, 2015, p. 31-32) 
Meaning of the word 'address' is open to interpretation, but notwithstanding the vagueness of the demand, its strength is also unclear. Is this a minimum requirement that all nurses must engage in, or a more general moral exhortation, something undertaken by good nurses? Does it require consideration of these issues in caring for individual patients or general political action directed at social justice? (Lipscomb, 2011, Kagan et al., 2010 ). Other codes use deontic words with clarity and explanation: The glossary at the start of the code published by the Nursing and Midwifery Board of Ireland (2014) includes the following:

Must: commands the action a nurse or midwife is obliged to take from which no deviation whatsoever is allowed (p.3).

Should: indicates a strong recommendation to perform a particular action from which deviation in particular circumstances must be justified (p.4).

The Irish code is structured around values, standards of conduct, and supporting guidance, and the deontic words are chosen with care within conduct statements:

You must act within the law and follow the rules and regulations of the Nursing and Midwifery Board of Ireland (p. 17).

You should be aware of your professional responsibility when using social media (p.17).

In the UK, the distinction is noted in documents regulating the medical profession, more detailed than the Irish nursing code:

In Good Medical Practice, we use the terms 'you must' and 'you should' in the following ways.

- 'You must' is used for an overriding duty or principle.

- 'You should' is used when we are providing an explanation of how you will meet the overriding duty.

- 'You should' is also used where the duty or principle will not apply in all situations or circumstances, or where there are factors outside your control that affect whether or how you can follow the guidance.

(General Medical Council (GMC), 2013, p.5)

The Australian Code of Professional Conduct does not use deontic language but its directive intention is clear:

While mandatory language such as 'must', 'shall' and 'will' is not used throughout this Code, it is important for nurses to understand that there is a presumption the conduct discussed is mandatory and therefore not discretionary for nurses practising nursing.

Nursing and Midwifery Board of Australia (2008b, p1)

The regulation of healthcare professionals in the UK has recently undergone a significant review by the Law Commissions, statutory independent bodies with the function of keeping 
the law under review, ensuring that it is 'fair, modern, simple and as cost effective as possible' (Law Commission, undated). The review concluded with recommendations including a draft Bill which, to the chagrin of the NMC, has not yet been presented despite the stated intention and sufficient parliamentary time at the end of the last parliament (NMC, 2015c).

The review considered, inter alia, the separation of standards and guidance and noted that most of the regulators who responded to consultation 'felt that their approach to guidance [...] provided clarity through the use of 'must' and 'should' (Law Commissions, 2014, p.103). Following this consultation, report and draft legislation, the NMC undertook its own consultation prior to revision of its code. The paper which accompanied the penultimate version, presented to and approved by the Council, stated that some concern has been raised to the effect that use of the phrase 'you must' made the 'code sound dictatorial and draconian rather than promoting a sense of ownership' (NMC, 2014b, p.4), but the directive phrasing was retained because, in line with observations in the Law Commissions' report, 'it is felt that retaining the phrase 'you must' makes it clear that these are not optional requirements ${ }^{13}$ and are expected standards for all nurses and midwives.' (NMC 2014b, p.4). Despite the recommendations of the Law Commissions' report there is no acknowledgement of the possible uses of deontic language in The Code and so there is potential for confusion about the status of clauses.

In the final section of The Code, headed 'promote professionalism and trust' it is stated that:

You should display a personal commitment to the standards of practice and behaviour set out in the code. You should be a model of integrity and leadership for others to aspire to. This should lead to trust and confidence in the profession from patients, people receiving care, other healthcare professionals and the public

(NMC, 2015a, p.12)

The final use of the word 'should' in this paragraph is in the epistemic rather than normative sense (Chrisman, 2012), that is a predictive claim is being made: that nurses displaying the commitment referred to will (probably) lead to trust and confidence. ${ }^{14}$ The other two 'shoulds' are normative, detailing expectation for personal commitment (whatever that means in practice). The board paper (NMC, 2014b) referred to the wording 'you must' indicating that it isn't an 'optional requirement' but unlike other codes discussed the use of deontic words is not explained in the Code or anywhere else. In any case, the 'should' statement is elaborated upon in more forthright terms in the clauses that follow, including: 'you must act as a role model of professional behaviour...' (NMC, 2015a, clause 20.8, p.15). It could be that the intention is that the initial section is a value based ethical-statement and not a conduct-statement but if so it is unlike similar sections elsewhere in the code which have descriptive rather than normative expression. Unlike the Irish nurse and the UK medical regulators, the NMC does not make it clear whether there is a distinction in usage of deontic words and, unlike the American Nursing Association, nor does it state that they are used interchangeably. As it is, this part of The Code is unclear.

\footnotetext{
${ }^{13}$ Perhaps it is churlish to suggest that one reason it can't be an 'optional requirement' is because the term makes no sense. A feature of a requirement is that it is non-optional.

${ }^{14}$ The strength of epistemic claims is also reflected in the use of modal verbs. While waiting for news of a friend's arrival, there is a difference between 'she should be home by now' and 'she must be home by now', related to the confidence with which I make the epistemic claim that she is at home.
} 
A different Standard document, Standards for Medicines Management (NMC, 2007) unambiguously states that 'Students must never administer or supply medicinal products without direct supervision' (NMC, 2007, standard 18, p.33). The accompanying explanatory guidance initially restates that opportunities 'must' be given to students 'but this must always be under direct supervision' but then notes, in the same paragraph that 'the registrant should support the student in gaining competence' and that 'as students progress through their training, their supervision may become increasingly indirect' (NMC, 2007, p.33, Snelling, 2012). No student that I have pointed this out to has any idea what it means. Pragmatic supervision can only be undertaken in direct contravention of the unambiguous and clearly directive standard.

Most guidance ${ }^{15}$ (as opposed to standards) documents previously published by the NMC have been withdrawn, apparently in the belief that The Code is sufficiently comprehensive to render them unnecessary (NMC, 2015d, Snelling, 2015), but those that remain, for example, guidance on using social media responsibly (NMC, 2015e), correctly make liberal use of the word 'should', restricting use of 'must' to quotations from the Code. Joint guidance from the GMC and the NMC on the duty on candour (NMC/GMC, 2015) uses both words but the format is clearly more aligned to the GMC where the difference is explained than the NMC where it is not. The NHS constitution, written primarily for patients, compounds the confusion by telling health care staff that 'they should aim to follow all guidance, standards and codes relevant to your role, subject to any more specific requirements of your employers' (Department of Health (DH), 2010, p.14).

Like the law, conduct-rules tell us what we must do and what we must not do, and while it is also the case that ethical-rules also set out the obligatory and the forbidden, they are additionally concerned with what is permissible or justified or aspired to. Both sets of rules have a role in education and regulation but clarity is required so that they can be distinguished. This necessarily requires precision with language, and regulators do not always provide it.

\section{Character and motivation: Compassion and kindness in codes}

\section{Compassion}

Perhaps the major challenge for the writers of both ethical-codes and conduct-codes is what to make of the notion of character. Many contemporary accounts of what it is to be good nurse include an assessment of character and the virtues (Armstrong, 2010, Sellman, 2011). One way this is manifest in codes is through consideration of the virtues of compassion and kindness, which feature in many codes as detailed in table 3 (page 14). The challenge of giving compassionate care has become perhaps the most pressing issue in UK professional healthcare in recent years. The significance of the episodes of very poor care at Mid Staffordshire FNHST and the reports (Francis, 2010, 2013) and actions which followed cannot be underestimated. There has been much political and professional discussion about what is required to ensure as far as possible that the episodes cannot be repeated, much of it

\footnotetext{
${ }^{15}$ In the UK, most healthcare regulators provide guidance, though it is unclear whether this is a legal duty or a power (Snelling 2015). The regulator in New Zealand believes that guidance is properly the domain of professional bodies and not regulators (Nursing Council of New Zealand, 2009).
} 
Table 3: Compassion and kindness in Code documents

\begin{tabular}{|c|c|c|c|}
\hline Organisation & Country & Type & \\
\hline International Council of Nurses & International & $\begin{array}{l}\text { Advisory / } \\
\text { professional }\end{array}$ & $\begin{array}{l}\text { The nurse demonstrates professional values such as respectfulness, responsiveness, compassion, trustworthiness } \\
\text { and integrity (p.2). No use of 'kind.' }\end{array}$ \\
\hline Nursing and Midwifery Council & UK & Regulatory & $\begin{array}{l}\text { You must treat people with kindness, respect and compassion (Clause } 1.1, \mathrm{p} .4 \text { ). } \\
\text { You must recognise when people are anxious or in distress and respond compassionately and politely (Clause } \\
2.6, \text { p.5). } \\
\text { You must recognise and respond compassionately to the needs of those who are in the last few days and hours } \\
\text { of life (Clause } 3.2, \text { p.5). } \\
\text { You must make sure that everyone you delegate tasks to is adequately supervised and supported so they can } \\
\text { provide safe and compassionate care (Clause } 11.2, \text { p.10). }\end{array}$ \\
\hline $\begin{array}{l}\text { Nursing and Midwifery Board } \\
\text { of Australia }\end{array}$ & Australia & Regulatory & $\begin{array}{l}\text { Not in any conduct statement, but present in explanation for statement } 8, \mathrm{p} .4 \text { : Nurses actively preserve the } \\
\text { dignity of people through practised kindness and respect for the vulnerability and powerlessness of people in } \\
\text { their care. Also discussed in footnotes }(13, \mathrm{p} .8) \text { : It was the view of the Council that kindness is irrefutably a } \\
\text { professional quality required of nurses. Compassion only used in footnote in relation to complaints (p.8) }\end{array}$ \\
\hline $\begin{array}{l}\text { Nursing and Midwifery Board } \\
\text { of Australia, Australian College } \\
\text { of Nursing, Australian Nursing } \\
\text { Federation. }\end{array}$ & Australia & Ethical & $\begin{array}{l}\text { Compassion noted in respect of immigrant health (p.2), and also note (in endnote) that 'The Council went on to } \\
\text { say that one of the greatest areas of complaint about nursing conduct is the absence of compassion or kindness.' } \\
\text { (p.9). The word kindness is used throughout the document, notably in value statement } 2 \text { : Nurses value respect } \\
\text { and kindness for self and others (p.1). }\end{array}$ \\
\hline $\begin{array}{l}\text { Nursing Council of New } \\
\text { Zealand }\end{array}$ & $\begin{array}{l}\text { New } \\
\text { Zealand }\end{array}$ & Regulatory & $\begin{array}{l}\text { Principle 1, Standard } 1.1 \text { (p. 9): Respect the dignity of health consumers and treat them with kindness and } \\
\text { consideration. No mention of compassion }\end{array}$ \\
\hline Canadian Nurses Association & Canada & $\begin{array}{l}\text { Professional } \\
\text { Endorsed by } \\
\text { some provincial } \\
\text { regulators }\end{array}$ & $\begin{array}{l}\text { Nursing values: nurses provide safe compassionate competent and ethical care (p.3) } \\
\text { Definition of compassionate: The ability to convey in speech and body language the hope and intent to relieve } \\
\text { the suffering of others. Compassion must coexist with competence. "Compassion is a relational process that } \\
\text { involves noticing another person's pain, experiencing an emotional reaction to his or her pain and acting in } \\
\text { some way to ease or alleviate the pain (Dutton Lilius and Kanov, 2007)" (p23.) } \\
\text { Glossary under 'Duty to Provide care': Nurses have a professional duty and a legal obligation to provide } \\
\text { persons receiving care with safe compassionate competent and ethical care. (p.24) }\end{array}$ \\
\hline $\begin{array}{l}\text { The Nursing Council of Hong } \\
\text { Kong }\end{array}$ & Hong Kong & Regulatory & No mention of compassion or kindness \\
\hline $\begin{array}{l}\text { Nursing and Midwifery Board } \\
\text { of Ireland }\end{array}$ & Ireland & Regulatory & $\begin{array}{l}\text { Principle } 3 \text { Value statement 1: Nurses and midwives who are competent, safety-conscious and who act with } \\
\text { kindness and compassion, provide safe, high-quality care (p.20). } \\
\text { Standard of conduct 4: You should be kind and compassionate in your practice (p.21) }\end{array}$ \\
\hline American Nurses' Association & USA & $\begin{array}{l}\text { Professional. } \\
\text { Regulatory in } \\
\text { some states }\end{array}$ & $\begin{array}{l}\text { Provision 1: The nurse practices with compassion and respect for the inherent dignity worth and unique } \\
\text { attributes of each person (p.1) }\end{array}$ \\
\hline
\end{tabular}


rather heated and, in the national newspapers, ill-informed and centred on education (Gillett, 2012, 2014). Paley's editorial in the journal Nurse Education Today (Paley, 2013) and a more considered piece in this journal (Paley, 2014) which suggested that the literature on social psychology had been insufficiently consulted in the examination of poor care provoked a number of critical responses. In brief, Paley suggested that situational factors including the sheer busy-ness of clinical areas contributes to an explanation of why some nurses behaved so poorly. The responses, from significant academic figures (Rolfe \& Gardner, 2014a, 2014b, Darbyshire, 2014, Timmins \& de Vries, 2014) considered that this explanation constituted wrongly excusing individuals. Their alternative explanation was that there is a compassion deficit in nursing, and that nurses are individually accountable, maintaining a tendency noted by Traynor et al. (2014) that the rise of managerialism responds to poor performance in terms of individual culpability rather than systems failure. ${ }^{16}$

In the aftermath of the Francis Reports the DH set out its vision and strategy for nursing midwifery and care staff. Entitled Compassion in Practice (DH 2012a), it introduced the 6Cs to the NHS environment (Bradshaw, 2015). Compassion is defined as 'how care is given through relationships based on empathy, respect and dignity - it can also be described as intelligent kindness, and is central to how people perceive their care' (DH, 2012a, p.13). There is little in the document about how compassion is to be facilitated and encouraged, but it is stated that metrics to measure it will be developed. ${ }^{17}$ Lack of detail about what compassion actually means is not surprising. In a critical review of peer-reviewed literature to 2013, McCaffery \& McConnell (2015) found only 20 relevant articles of which only 8 were research. There were, however, over 2000 other publications identified: 'editorials, book reviews, letters to the editor and even obituaries' $(2015, \mathrm{p} .2)$, suggesting that though much discussed there is little known about compassion in nursing (Ledoux, 2015) and how it can be effectively promoted and ensured, not least how it is represented in regulatory

documentation. Most of the peer-reviewed papers identified were from the UK, possibly as a result of the rigorous public debate, but compassion is included in most of the codes reviewed for this paper, with the notable exception of that from Hong Kong, a regulatory conduct-code which does not mention it at all.

Ethical-codes that detail aspirational values can reinforce the position that a good nurse has a caring disposition. For example the CNA Code of Ethics states that 'nurses provide safe compassionate competent and ethical care'(CAN, 2008, p.8), and the ANA's provision 1 states that 'The nurse practices with compassion and respect for the inherent dignity worth and unique attributes of each person' (ANA, 2015, p. 1). It is difficult to argue with these sorts of statements, but these value statements pose a number of problems when translated to regulatory conduct-codes, principally the simple truth that individuals cannot be required to have certain dispositions. The CNA Code of Ethics defines compassionate as:

The ability to convey in speech and body language the hope and intent to relieve the suffering of others. Compassion must coexist with competence. "Compassion is a relational process that involves noticing another person's pain, experiencing an emotional reaction to his or her pain and acting in some way to ease or alleviate the pain (Dutton Lilius and Kanov, 2007)"

\footnotetext{
${ }^{16}$ In calling for shared objectives between system and professional regulators, The Professional Standards Authority, the UK organisation that co-ordinates healthcare regulators, notes that evidence of the link between behaviour and environment is compelling (Professional Standards Authority, 2015).

${ }^{17}$ See Papadopoulos and Ali's (2015) integrative review of tools to measure compassion, and Sturgeon (2008) on earlier attempts to introduce a measure.
} 
(CNA, 2008, p. 23)

The key word here is emotional, a response not fully under conscious control. A nurse cannot choose to have an emotional response. The CNA also states that: 'Nurses have a professional duty and a legal obligation to provide persons receiving care with safe compassionate competent and ethical care' (CAN, 2008, p.24). The nature of the legal obligation is not clear, but some provincial regulators (for example, the College and Association of Registered Nurses of Alberta) have endorsed the CNA Code of Ethics and refer to it in fitness to practice hearings. A close reading of these documents shows that having an emotional reaction to another's suffering is apparently a legal and professional requirement for some canadian nurses. In contrast the definition of compassion in the glossary of the ANA codes does not use the word 'emotional' but it is clear that compassion is a virtue:

An awareness of suffering, tempered with reason, coupled with the desire to relive the suffering; a virtue combining sympathy, empathy, benevolence, caring and mercy. Used with the cognitive and psychomotor skills of healing to meet the patient's needs

(ANA, 2015, p.41)

Emotional responsiveness as part of a caring disposition is a feature of good nursing, but too much of a good thing is bad, as noted in a consultation draft of the latest NMC Code: 'You must maintain clear professional boundaries (including sexual, personal and emotional boundaries) at all times with people in your care, their families and carers' (NMC, 2014d, clause 20.6, p. 15). During consultation the phrase was objected to on the ground that it was implied that there was to be no emotional engagement (NMC, 2014d, Snelling, 2015), and the clause now refers to 'clear professional boundaries' (NMC, 2015a, clause 20.6, p.15). This is ambiguous, but the possibility of too much emotional engagement makes perfect sense to Aristotelians as excess as well as deficiency in virtues is to be avoided.

Conduct-rules requiring compassion make no sense at all. Some nurses do not feel an emotional response, and some patients do not elicit it. Following Aristotle (1991), Martha Nussbaum's account of compassion (Nussbaum, 1996, 2001) includes as necessary features that suffering is severe and undeserved. Though she refers to compassion in a factual rather than normative sense, what compassion is rather than what it ought to be, these features are likely to excite health care professionals and their regulators who would not see lack of desert or severity as reason not to be compassionate. But despite Nussbaum's emphasis on the cognitive aspects of compassion, reflected in the ANA definition, the initial response required is at least partly emotional, though someone observing a compassionate response could have no knowledge and little idea of whether it is based on emotion, reason, or fear of censure or a combination of all three. Being compassionate and behaving as though compassionate are two different things, and this is what might have been meant when the NMC stated that The Code is what good nursing 'looks like' (NMC, 2015a, p.3) rather than what it is. Bramley and Matiti's (2014) study which asked patients about their experiences of compassionate care found that 'the smallest of nursing actions can be viewed as a compassionate action by patients...' (2014, p.2797), and Cameron et al. (2013) studied encounters between oncologists and their patients to develop a taxonomy of 'compassionate behaviours' which can then be taught. An uncompassionate response can be made to look compassionate, but a genuine and emotional compassionate response cannot be regulated for. Forcing people to write with their left hand does not make them left handed. 


\section{Kindness}

Use of the concept kindness may be an effective response to the challenge of regulating for compassion. Kindness is defined in the Nursing and Midwifery Board of Australia Code of Ethics $^{18}$ (2008a, p. 3) as 'the demonstration of simple acts of gentleness, consideration and care'. A clause concerning kindness was introduced in the previous version of the NMC Code (2008) for the first time: 'You must treat people kindly and considerately' (NMC, 2008d, Clause 3, p.3), amended in the latest version so that the word compassion is also used: 'you must treat people with kindness, respect and compassion (NMC, 2015a, clause 1.1, p.4)'. Use of the word kind and its cognates in these clauses can be related simply to conduct; It is possible that individuals can act with kindness even if they are not a kind person. ${ }^{19}$ Kindness has a lower threshold and unlike compassion does not require emotional engagement. Compassion entails kindness but kindness does not require compassion.

The concepts kindness and compassion are often conflated ${ }^{20}$ as in the NMC code statement cited, and apart from an excellent paper by Faust (2009) there is little to be found in the healthcare literature on kindness and how it is to be distinguished from compassion in professional healthcare. In the UK, the GMC, unhindered by the emotional language of compassion ${ }^{21}$ instead requires that '[doctors] must be polite and considerate' (GMC, 2014, clause 46, p.16). Even if use of the less demanding and act centred concept of kindness solves the problem of the impossibility of regulating for character, there remains the problem of extent. How much kindness is required?

A logical conundrum in definition is suggested by Gallagher's (2012) editorial which details a small act of kindness for a woman near the end of her life. Student Nurse Owen extended his shift to go to a MacDonald's restaurant to get a dying patient a soft ice cream, what turned out to be her last meal. Gallagher describes this act of kindness as supererogatory, a category of permitted moral action which is not required (Mellema, 1991). According to The Code, treating people with kindness is required and so it cannot be regarded as supererogatory, yet the act described by Gallagher does seem to go 'beyond the call of duty', even for a nurse, such that if he had not considered the trip to McDonald's, or declined to go when asked (and able) he would not have been blameworthy, a further feature of a supererogatory act.

Recently I travelled to work with Martin, my friend and colleague, and after parking the car we walked together to the building. He was carrying two bags and I had a light rucksack over a shoulder. Awkwardly taking his keys from his pocket, he dropped the bunch on the floor, and I bent down to pick them up and returned them to him. I know that he occasionally suffers from a sore back, and he had declined my earlier offer of taking one of his bags. Under the definition offered by the Nursing and Midwifery Board of Australia, that was a

\footnotetext{
${ }^{18}$ The Code of Ethics is Australia is produced and published 'under the auspices of Australian Nursing and Midwifery Council, Australian College of Nursing, Australian Nursing Federation.' These three organisations represent the ICN's three pillars. The Code of Conduct applying to Australian nurses is produced by the regulator, the Australian Nursing and Midwifery Council.

${ }^{19}$ Perhaps the clearest example of this in popular culture is the gifted physicist Dr Sheldon Cooper in the popular US television programme The Big Bang Theory who cannot be described as a kind person but knows and acts upon the social convention that hot beverages should be offered to people who are upset. Sheldon wouldn't be a good nurse, but as a roommate, and given the improbability of personality change, this is probably the most that can be expected (or required) of him.

${ }^{20}$ In the UK patients' rights are set out in the NHS constitution (DH 2010). It states that 'We ensure that compassion is central to the care we provide and respond with humanity and kindness to each person's pain, distress, anxiety or need.' (p5).

${ }^{21}$ See Pellegrino \& Thomasma (1993) for a discussion of compassion as a virtue in medical practice.
} 
kind act, but had I failed to pick up his keys and simply watched as he put down his bags and picked them up himself, he (and probably an onlooker) would have been justified in blaming me for failure to assist. Owen's act of facilitating a patient's final pleasure and mine of preventing a friend from momentary inconvenience at trivial cost can both plausibly be considered kind, and yet they do not seem to be the same thing, and this difference would persist if Martin had been my patient or a stranger. One act was in the double context of professional care and the relationship between student and assessor, the other between friends and yet also colleagues who are required to work together. It could be argued that both Owen and I had self-regarding motivation for our acts. If individuals are to be taken to task for failing to do something, it is important to be clear what this failure looks like. If the acts I have described are unequal, so is their negation.

\section{The negation of kindness}

At least five different meanings of absence of kindness can be described. First is simply where kindness is not called for. In nursing this could be a simple everyday brief interaction of answering the phone or responding to a closed question. For example, confirming to a visitor that visiting time starts at 1400. A simple nod or monosyllabic 'yes' cannot be described as kind, but neither can it be required to be.

There is a difference between (second) not-being-kind and (third) being unkind. Not-beingkind is simply the absence of kindness when it could be called for whereas being unkind is a harsher thing altogether. Not-being-kind is likely to be a failure to do something, whereas being unkind is more likely (though not exclusively as my example shows) concerned with actions. Had Owen not gone to McDonald's it would have been not-being-kind, but if I had failed to pick up Martin's key it would have been unkind. Thinking about these examples is a start to unpicking what treating people with kindness requires. One way of distinguishing between being unkind and not-being-kind, possibly helpful in describing the moral status of acts and their omission, is that Owen's act (as supererogatory) is optional, whereas mine was not; its obligatory status is derived from a general obligation of beneficence calculated from knowing the minimal costs to me, and the actual and potential benefit to him. ${ }^{22}$ However, in the context of professional regulation this distinction amounts to useless circularity, as it condenses to a conduct-rule requiring that 'you must do obligatory things. ${ }^{23}$

In her important book Illness: The Cry of the Flesh, Havi Carel gives her account of, for the nurse, an everyday encounter. Carel, who is diagnosed with a chronic and potentially life limiting respiratory illness is at a hospital for a lung function test:

A lovely nurse, Simone, is usually there, chatting to me, telling me about her boyfriend. But this time she is not there. Another nurse, sullen and unfriendly, leads me to the test room. She sets up the machine without saying a word, hands me a tube and tells me to blow in it as hard and fast as I can [...]

\footnotetext{
${ }^{22}$ In a similar vein, it has been argued that blood donation, considered and presented as supererogatory, should rather be considered as obligatory (Snelling, 2014).

${ }^{23}$ Use of the word (in) appropriate also shows this circularity. The conduct-rule 'you must make sure you do not express your personal beliefs (including political, religious or moral beliefs) to people in an inappropriate way' (NMC 2015a, clause 20.7, p15) amounts to requiring that you must not do unsuitable things (Snelling 2015).
} 
I ask her for my result. "1.1" the nurse says, with no trace of emotion in her voice...I look at the nurse. She stands there stony but for her slight impatience. Now I'm crying and can't do the other tests. I'm spoiling her day, getting her behind schedule. I collect myself; ask her for a glass of water. A sulky hand presents me with a dripping paper cup. She doesn't look at me or say anything. I am alone.

(Carel, 2008, p.38)

Fetching a cup of water in response to a request and presenting it in the manner described can hardly be regarded as treating Carel with kindness, but can we regard her treatment as notbeing-kind, or unkind? Carel further discusses the cool demeanour of the doctors during consultation and notes a dividing line between "us" (patients) and "them" (healthcare professionals) and suggests that it might be necessary:

Perhaps doctors and nurses need the dividing line to sustain their sanity in the harsh world of illness, pain and death. Perhaps no one can witness sorrow and offer empathy on a daily basis.

(Carel, 2008, p.40-41)

She began to talk to her friends and medical audiences about her experiences, and found that:

There seemed to be no consistent line among those I spoke to; it was an aspect of medical work that was entirely up to the individual.

(Carel, 2008, p. 41)

Carel's book is a compact yet profound meditation on illness and how it affects her and it asks some challenging philosophical questions which can also be applied to the everyday encounters that characterise healthcare practice. The attitudes of the nurses and doctors she describes are indeed inconsistent, but the view from patients perhaps equally so. Carel appreciated Simone's friendly boyfriend-chat but many others would not. A key question for nurses reading and reflecting on Carel's experiences would be to situate the nurses' actions within the standards expressed in codes. Is Simone's chat the kind action of a good nurse, and does the conduct of her unnamed and stonily impassive replacement fall below that of the just-good-enough nurse? The regulator's role here, via a conduct-code is to challenge and change the situation that Carel perceived. This aspect of medical (sic) work should be 'up to the individual' only if it is above the minimum standard.

The fourth category of negation of kindness is faux-kindness or procedural kindness by which I mean an apparently other regarding act performed grudgingly. It might include the fixed smile and palpably false wish that a customer 'have a nice day' (Wang, 2016) but also acts similar to that performed by Simone's replacement. Although, unlike a compassionate act, a kind act might not be driven by desire (Phillips \& Taylor, 2009) or virtue there is the possibility that the recipient is unable to tell the difference. A faux-kind act shows to the recipient, consciously or unconsciously, that it is not genuine, that coercion is being exercised to motivate it. Spielthenner (2015) argues that it is obvious that the strongest motivation for abiding by a professional code is the possibility of sanctions, even though not all violations will result in complaint, investigation and sanction. ${ }^{24}$ An act like this, performed under duress

\footnotetext{
${ }^{24}$ Similar issues can be seen in relation to traffic offences where increased police presence is known to reduce speeding (Walter et al.., 2011), so that the threat of sanction gives a reason to reduce speed, rather than
} 
can hardly be considered a kind act because its motivation, to avoid sanction is ultimately self-regarding. ${ }^{25}$

The fifth account is not so much the absence of kindness as its opposite, similar to the 'callous indifference' that Robert Francis found at Mid Staffordshire FNHST or the deliberate cruelty that can be seen in disciplinary hearings and media reports. This is of a different order to the simple lack of kindness and seems less problematic for fitness to practice cases. Some cases where deliberate cruelty has occurred may in future also be prosecuted in the criminal courts following enactment of the Criminal Justice and Courts Act 2015, ${ }^{26}$ which makes it an offence for a care worker (including a nurse) to ill-treat or wilfully neglect a person in their care (Griffith 2013, 2015). There is no definition of ill treatment in the Act, and so the courts use ordinary English meaning. In answering the question, 'what is abuse', the code of practice to the Mental Capacity Act states that: 'The word 'abuse' covers a wide range of actions. In some cases, abuse is clearly deliberate and intentionally unkind.' (Department for Constitutional Affairs, 2007, p.244). It is unclear as to whether or how far the criminal threshold for ill-treatment and neglect falls below the threshold in fitness to practice cases. A brief reading of cases involving individuals being struck off the register at the NMC suggests that the facts presented there could also satisfy the criminal threshold, though criminal cases require a higher standard of proof. ${ }^{27}$

In the UK, the problem of regulating for compassion is a particularly nursing issue. The words kindness and compassion do not appear in UK codes for doctors (GMC, 2013) ${ }^{28}$ and other healthcare professionals (HCPC, 2008). Including compassion and kindness as part of an agent centred ethical framework is apparently unproblematic probably because it is regarded as self-evident. There is little attempt to explain what compassion is, and no justification as to why nurses should have it, or how much they should have. However desirable in ethical terms, including compassion and kindness in conduct-rules presents a number of problems. Importantly there is little discussion on what the absence of kindness or compassion amounts to and at what level it becomes liable for sanction. Recent reforms of the revalidation process (NMC, 2015f) requires nurses to undertake reflection with reference to The Code and so an understanding of what is required, not just to claim the title of 'good nurse' but also to understand the features and actions of a just-good-enough-nurse is required but not provided.

appealing to a moral argument or authority. Interestingly, a Norwegian study reported that increasing the likelihood of being caught would reduce speed more than steeper penalties (Ryeng, 2012).

${ }^{25}$ Also in the UK, the healthcare leadership model of the NHS Leadership Academy questions, as an essential component of leadership: 'Do I carry out genuine acts of kindness for my team?' (NHS Leadership Academy, 2013, emphasis added).

${ }^{26}$ Ill treatment and wilful neglect had already been criminal offenses under the Mental Capacity Act but applied on to those deemed not to have capacity. The numbers of prosecutions has been increasing: Annual figures from 2008 onwards are $36,47,68,81,85$. It is estimated that there will be 240 cases annually when the criminal sanction applies to all patients in care (DH, 2012b).

27 The Health and Social care Act 2008 imposed the civil standard for proof, on the balance of probabilities, in fitness to practice hearings from 2009. Previously the criminal standard, beyond reasonable doubt, applied.

${ }^{28}$ In contrast, the American Medical Association includes compassion in its first principle: 'A physician shall be dedicated to providing competent medical care, with compassion and respect for human dignity and rights.' (American Medical Association, 2001) 


\section{Conclusion}

I have highlighted a number of significant differences between ethical-codes and conductcodes which correspond generally to the difference between ethics and law. Examples from around the world show that different regulatory systems and the organisations within them use their codes in different ways. The examples I have provided largely in the UK context show that the NMC does not distinguish between the types of code and as a result the code that has recently been consulted upon and issued is a confusing conflation of the two types. Codes are dynamic and meaningful documents, given prominence in education and practice. In recently issued requirements for periodic revalidation (NMC, 2015f) The Code will be scrutinised and juxtaposed against episodes from practice in a process which requires reflection and aims to 'to raise awareness of the Code and professional standards expected of nurses and midwives' (NMC, 2015f, p.5). This requires a document which is clear about its purpose and precise with its language so that its requirements can be clearly understood.

More generally the differences I have identified can be considered by nurses in all countries encouraging reflection about the purpose and nature of codes and their impact on practice as well as by the writers of codes from each of the organisation types identified by the ICN. Codes of ethics and codes of conduct will remain essential parts of both professional practice and regulation, and they will be better able to support the functions of their issuing organisations if the metaethical concerns I have identified are more clearly articulated and addressed 


\section{References}

American Medical Association (2001) Principles of Medical Ethics. [on line] http://www.amaassn.org/ama/pub/physician-resources/medical-ethics/code-medical-ethics/principlesmedical-ethics.page [Accessed $11^{\text {th }}$ January 2016].

American Nurses Association (2015) Code of Ethics for Nurses. [on line]

http://www.nursingworld.org/codeofethics [Accessed $11^{\text {th }}$ January 2016].

Aristotle (1991) The Art of Rhetoric. London: Penguin Books

Armstrong A. (2010) Nursing Ethics: A Virtue-Based Approach. Basingstoke: Palgrave Macmillan.

Beauchamp T.L. \& Childress, J.F. (2013) Principles of Biomedical Ethics (seventh edition). Oxford: Oxford University Press.

Bradshaw A. (2015) An analysis of England's nursing policy on compassion and the 6Cs: the hidden presence of M. Simone Roach's model of caring. Nursing Inquiry. Article first published online: 8 JUN 2015. DOI: 10.1111/nin.12107

Bramley L. \& Matiti M. (2014) How does it really feel to be in my shoes? Patients' experiences of compassion within nursing care and their perceptions of developing compassionate nurses. Journal of Clinical Nursing, 23(19-20), 2790-2799.

Cameron R. A. Mazer B. L. DeLuca J. M. Mohil, S. G. \& Epstein R. M. (2013) In search of compassion: a new taxonomy of compassionate physician behaviours. Health Expectations. DOI: $10.1111 /$ hex.12160

Canadian Nurses Association (2008) Code of Ethics for Registered Nurses. [on line] http://www.cna-nurses.ca/CNA/practice/ethics/code/default_e.aspx [Accessed 11th January 2016].

Carel H. (2008) Illness: The Cry of the Flesh. Durham: Acumen Publishing Limited.

Chrisman M. (2012) 'Ought'and Control. Australasian Journal of Philosophy 90(3), 433-451.

Darbyshire P. (2014) Character assassination? Response to John Paley, "social psychology and the compassion deficit”. Nurse Education Today, 34(6), 887-889.

Davies C. \& Beach A. (2000) Interpreting professional self-regulation. Routledge: London.

Department for Constitutional Affairs (2007) Mental Capacity Act 2005 Code of Practice. London: The Stationary office.

Department of Health (2010) The NHS constitution. London: Department of Health.

Department of health (2012a) Compassion in Practice. London: Department of Health.

Department of health (2012b) Impact assessment: Criminal Offence of ill-treatment or wilful neglect. London: Department of Health. [on line] https://www.gov.uk/government/uploads/system/uploads/attachment_data/file/285428/20 140226_Wilful_Neglect_IA__for_publication.pdf [11th January 2016]. 
De Prez P. (2002) Self-Regulation and Paragons of Virtue: The Case of 'Fitness to Practise'. Medical Law Review, 10(1), 28-56.

Duncan S. Thorne S. \& Rodney P. (2015) Evolving trends in nurse regulation: what are the policy impacts for nursing's social mandate? Nursing Inquiry, 22(1), 27-38.

Edwards S.D. (2009) Nursing Ethics: A Principle-Based Approach (second edition). Basingstoke: Palgrave Macmillan.

Faust H. S. (2009) Kindness, not compassion, in healthcare. Cambridge Quarterly of Healthcare Ethics, 18(03), 287-299.

Francis R. (2010) Independent Inquiry into Care Provided by Mid Staffordshire NHS Foundation Trust January 2005 - March 2009. London: The Stationary Office.

Francis R. (2013) Report of the Mid Staffordshire NHS Foundation Trust Public Inquiry. London: The Stationary Office.

Freedman M. H. (2013) Jury nullification: What it is, and how to do it ethically. Hofstra Law Review, 42, 1125-1138

Fry S. \& Johnstone M-J. (2008) Ethics in nursing practice: a guide to ethical decision making. Third edition. Oxford: John Wiley and sons

Gallagher, A (2012) Acknowledging small acts of kindness. Nursing Ethics, 19(3) 311-312

Gallagher A. \& Hodge S. (2012) Introduction. In A. Gallagher \& S. Hodge (eds) (2012). Ethics, law and professional issues: A practice-based approach for health professionals. Basingstoke: Palgrave Macmillan. Chapter 1 pp 1-25.

Garrett B. M. \& MacPhee M. (2013) The slippery slope of nursing regulation: challenging issues for contemporary nursing practice in Canada. Nursing leadership, 27(3), 51-69.

General Medical Council (2013) Good Medical Practice [on line] http://www.gmcuk.org/guidance/good_medical_practice.asp [Accessed 11th January 2016].

Gillett K. (2012). A critical discourse analysis of British national newspaper representations of the academic level of nurse education: too clever for our own good? Nursing Inquiry, 19(4), 297-307.

Gillett K. (2014) Nostalgic constructions of nurse education in British national newspapers. Journal of Advanced Nursing, 70(11), 2495-2505.

Griffith R. (2013) Extending the scope of wilful neglect will result in paternalistic nursing care. British Journal of Nursing, 22(20)1190-1191

Griffith R. (2015) Patient protection: ill-treatment and wilful neglect. British Journal of Nursing, 24(11) 600-601

Groefsema M. (1995). Can, may, must and should: A relevance theoretic account. Journal of linguistics, 31(1), 53-79.

Health and Care Professions Council (2008) Standards of conduct, performance and ethics. [on line] http://www.hcpc-uk.co.uk/publications/index.asp?id=38\#publicationSearchResults [Accessed 11th January 2016]. 
Holt J. (2010) Professional Issues. In Sellman D and Snelling P.C. (2010) becoming a Nurse: a textbook for professional practice. Harlow: Pearson Education. Chapter 1 pp 1-36.

Hutchison J. S. (2015) Scandals in health-care: their impact on health policy and nursing. Nursing Inquiry. Article first published online : 19 JUL 2015, DOI: 10.1111/nin.12115

Illych I. (1977). Disabling Professions. In Illich I. Zola I.K. McKnight J. Caplan J. Shaiken H. (1977) Disabling Professions New York: Marion Boyars. Chapter 1, pp 11-39.

International Council of Nurses (2006) Code of Ethics for Nurses [on line] http://www.icn.ch/about-icn/code-of-ethics-for-nurses/ [Accessed 11th January 2016].

International Council of Nurses (2015) Our Mission, Strategic Intent, Core Values and Priorities [on line] http://www.icn.ch/who-we-are/our-mission-strategic-intent-core-values-andpriorities/ [Accessed 11th January 2016].

Johnstone M-J. (2016) Bioethics - a nursing perspective, sixth edition. Sydney: Churchill Livingstone.

Kagan P.N. Smith M.C. Cowling W.R. \& Chinn P.L. (2010) A nursing manifesto: an emancipatory call for knowledge development, conscience, and praxis. Nursing Philosophy, 11(1), 67-84.

Kangasniemi M. Pakkanen P. \& Korhonen A. (2015) Professional ethics in nursing: an integrative review. Journal of Advanced Nursing, 71(8), 1744-1757

Law Commission, Scottish Law Commission, Northern Ireland Law Commission (2014) Regulation of Health Care Professionals; Regulation of Social Care Professionals in England. London: Law Commission http://lawcommission.justice.gov.uk/docs/lc345_regulation_of_healthcare_professionals. pdf [Accessed 11th January 2016].

Law Commission (no date). About Us. http://lawcommission.justice.gov.uk/about-us.htm [Accessed 11th January 2016].

Ledoux K. (2015) Understanding compassion fatigue: understanding compassion. Journal of Advanced Nursing 71(9), 2041-2050.

Lipscomb M. (2011) Challenging the coherence of social justice as a shared nursing value. Nursing Philosophy, 12(1), 4-11.

McCaffrey G. \& McConnell S. (2015) Compassion: a critical review of peer-reviewed nursing literature. Journal of Clinical Nursing, 24(19-20), 3006-3015.

Meulenbergs T. Verpeet E. Schotsmans P. \& Gastmans C. (2004) Professional codes in a changing nursing context: literature review. Journal of Advanced Nursing, 46(3), 331336.

Mellema G. (1991) Beyond the Call of Duty. Albany: State University of New York Press.

NHS Leadership Academy (2013) Healthcare Leadership Model:The nine dimensions of leadership behaviour. [on line] http://www.leadershipacademy.nhs.uk/wpcontent/uploads/dlm_uploads/2014/10/NHSLeadership-LeadershipModel-colour.pdf [Accessed 11th January 2016]. 
Nursing and Midwifery Board of Australia (2008a) Code of Ethics for Nurses in Australia http://www.nursingmidwiferyboard.gov.au/Codes-Guidelines-Statements/Professionalstandards.aspx [Accessed 11th January 2016].

Nursing and Midwifery Board of Australia (2008b) Code of Professional Conduct for Nurses in Australia http://www.nursingmidwiferyboard.gov.au/Codes-GuidelinesStatements/Professional-standards.aspx [Accessed 11th January 2016].

Nursing and Midwifery Board of Ireland (2014) Code of Professional Conduct and Ethics for registered nurses and registered midwives [on line] http://www.nursingboard.ie/en/code/new-code.aspx [Accessed 11th January 2016].

Nursing and Midwifery Council (2007) Standards for Medicines Management [on line] http://www.nmc.org.uk/globalassets/siteDocuments/NMC-Publications/NMC-Standardsfor-medicines-management.pdf [Accessed 11th January 2016].

Nursing and Midwifery Council (2008) The Code: Standards of Conduct Performance and Ethics for Registered Nurses and Midwives. http://www.nmc.org.uk/globalassets/sitedocuments/standards/the-code-a4-20100406.pdf [Accessed 11th January 2016].

Nursing and Midwifery Council (2012) Indicative sanctions guidance to panels http://www.nmc.org.uk/globalassets/sitedocuments/ftp_information/indicative-sanctionsguidance.may-12.pdf [Accessed 11th January 2016].

Nursing and Midwifery Council (2014a) Standards and guidance review cycle 2014/2017. Presented in board papers for council meeting 26th March 2014, item 10, pp 111-112 http://www.nmc.org.uk/globalassets/siteDocuments/CouncilPapersAndDocuments/Counc il-2014/Council-papers---OPEN-26-March-2014-FINAL.pdf [Accessed 11th January 2016].

Nursing and Midwifery Council (2014b). Revision of the Code. Presented in board papers for council meeting 3rd December 2014, item 11, pp 177- 185 http://www.nmc.org.uk/globalassets/sitedocuments/councilpapersanddocuments/council2014/council-papers-20141203-final-pdf.pdf [Accessed 11th January 2016].

Nursing and Midwifery Council Code Evidence Report (2014c) London: Nursing and Midwifery Council [on line] http://www.nmc.org.uk/globalassets/siteDocuments/Consultations/2014/Code-evidencereport.pdf [Accessed 11th January 2016].

Nursing and Midwifery Council (2014d) The Code: Standards of Conduct Performance and Ethics for Nurses and Midwives - Draft revised version. London: Nursing and Midwifery Council http://eoe.hee.nhs.uk/files/2014/04/Draft-revised-code.pdf [Accessed 11th January 2016].

Nursing and Midwifery Council (2015a) The Code: Professional Standards of Practice and Behaviour for Nurses and Midwives. [on line] http://www.nmc.org.uk/standards/code/ [Accessed 11th January 2016].

Nursing and Midwifery Council (2015b). Our role: what we do [on line] http://www.nmc.org.uk/about-us/our-role/ [Accessed 11th January 2016]. 
Nursing and Midwifery Council (2015c) Queen's Speech briefing - the importance of a Bill modernising health professional regulation. London: Nursing and Midwifery Council. http://www.nmc.org.uk/globalassets/sitedocuments/press/queens-speech-briefing--theimportance-of-a-bill-modernising-health-professional-regulation.pdf [11th January 2016].

Nursing and Midwifery Council (2015d). Guidance underpinning the Code. Presented in Board papers for council meeting 28th January 2015 item 15, pp 159-162. http://www.nmc.org.uk/globalassets/sitedocuments/councilpapersanddocuments/council2015/council-28-january-2015-agenda-papers-final.pdf [Accessed 11th January 2016].

Nursing and Midwifery Council (2015e) Guidance on using social media responsibly [on line] http://www.nmc.org.uk/standards/guidance/social-networking-guidance/ [Accessed 11th January 2016]

Nursing and Midwifery Council (2015f) Revalidation

http://www.nmc.org.uk/globalassets/sitedocuments/revalidation/how-to-revalidatebooklet.pdf [Accessed 11 th January 2016].

Nursing and Midwifery Council / General Medical Council (2015) Openness and honesty when things go wrong: the professional duty of candour http://www.nmc.org.uk/globalassets/sitedocuments/nmc-publications/openness-andhonesty-when-things-go-wrong--the-professional-duty-of-candour.pdf [Accessed 11th January 2016

Nursing Council of Hong Kong (2015) Code of Ethics and Professional Conduct for Nurses in Hong Kong. [on line ] http://www.nchk.org.hk/filemanager/en/pdf/conduct.pdf [Accessed 11th January 2016].

Nursing Council of New Zealand (2009). Code of Conduct for Nurses. [on line] http://nur3425s2.handel.2day.com/Code\%20of\%20Conduct\%20Nov09.pdf [Accessed 11th January 2016].

Nussbaum M. (1996) Compassion: The basic social emotion. Social Philosophy and Policy, 13(1), 27-58.

Nussbaum M.(2001) Upheavals of Thought: The Intelligence of Emotions. Cambridge: Cambridge University Press.

Paley J. (2013) Social psychology and the compassion deficit. Nurse Education Today, 33(12), 1451-1452.

Paley J. (2014) Cognition and the compassion deficit: the social psychology of helping behaviour in nursing, Nursing Philosophy, 15(4), 274-287.

Papadopoulos I. \& Ali S. (2015) Measuring compassion in nurses and other healthcare professionals: An integrative review, Nurse Education in Practice http://dx.doi.org/10.1016/j.nepr.2015.08.001

Pattison, S. (2001). Are nursing codes of practice ethical?. Nursing Ethics, 8(1), 5-18.

Pattison S. \& Wainwright P. (2010) Is the 2008 NMC Code ethical? Nursing Ethics, 17(1), 9-18. 
Pellegrino E.D. \& Thomasma D.C. (1993) The Virtues in Medical Practice. New York: Oxford University Press.

Phillips A. \& Taylor B. (2009) On kindness. London: Hamish Hamilton.

Professional Standards Authority (2015) Rethinking regulation. [on line] http://www.professionalstandards.org.uk/docs/default-source/psa-library/rethinkingregulation.pdf?sfvrsn $=2$ [Accessed 11th January 2016].

Pyne R. (1992) Professional Discipline in Nursing Midwifery and Health Visiting (second edition) London: Blackwell Scientific Publications

Rolfe G. \& Gardner L. D. (2014a) The compassion deficit and what to do about it: a response to Paley. Nursing Philosophy, 15(4), 288-297.

Rolfe G. \& Gardner L. (2014b) Invisible gorillas and red herrings: a response to Paley (2013). Nurse Education Today, 34(6), 954-957.

Royal College of Nursing (2013) Mid Staffordshire NHS Foundation Trust Public Inquiry Report: Response of the Royal College of Nursing. [on line] https://www.rcn.org.uk/_data/assets/pdf_file/0004/530824/francis_response_full_FINA L.pdf [Accessed 11th January 2016].

Royal College of Nursing (2015) Extraordinary General Meeting - $Q$ and A [on line] http://www.rcn.org.uk/newsevents/egm/q_and_a [Accessed 11th January 2016].

Ryeng E.O. (2012) The effect of sanctions and police enforcement on drivers' choice of speed, Accident Analysis \& Prevention, 45,446-454.

Sasso L. Stievano A. Jurado M.G. Rocco G. (2008) Code of Ethics and conduct for European nursing. Nursing Ethics, 15; 821-36.

Secretary of State for Health (2007) Trust Assurance and Safety: The Regulation of Health Professionals in the 21st Century. London: the Stationery Office

Sellman D (2011) What Makes a Good Nurse: Why the Virtues are Important for Nurses. London: Jessica Kingsley.

Snelling P. C. (2012). Saying something interesting about responsibility for health, Nursing Philosophy, 13(3), 161-178.

Snelling P. C. (2014) Challenging the moral status of blood donation. Health Care Analysis, 22(4), 340-365.

Snelling P.C. (2015) Can the revised UK code direct practice? Nursing Ethics Published online before print November 30, 2015, doi: 10.1177/0969733015610802

Spielthenner G. (2015) Why comply with a code of ethics? Medicine, Health Care and Philosophy, 18(2), 195-202.

Sturgeon D. 2008 Measuring compassion in nursing Nursing Standard, 22(46) 42-43.

Timmins F. \& de Vries J. M. (2014) Nurses are not bystanders: A response to Paley. Nurse Education Today, 10(34), 1269-1271. 
Traynor M. Stone K. Cook H. Gould D. \& Maben J. (2014). Disciplinary processes and the management of poor performance among UK nurses: bad apple or systemic failure? A scoping study. Nursing Inquiry, 21(1), 51-58.

Walter L. Broughton J. and Knowles J. (2011) The effects of increased police enforcement along a route in London, Accident Analysis \& Prevention, 43(3), 1219-1227.

Wang, Y (2016). Smiling through clenched teeth: why compassion cannot be written into the rules. Journal of Medical Ethics, 42:7-9 